\title{
Analisis Kesulitan Siswa dalam Pemahaman Belajar serta Penyelesaian Masalah Ruang Dimensi Tiga
}

\author{
Lamanda Ayuningrum $^{1 *}$, Arie Purwa Kusuma ${ }^{2}$, \& Nurina Kurniasari Rahmawati ${ }^{3}$ \\ 1.2.3. STKIP Kusuma Negara
}

\section{INFO ARTICLES}

\section{Article History:}

Received: 27-11-2019

Revised: 26-12-2019

Approved: 27-12-2019

Publish Online: 29-12-2019

Key Words:

Difficulty understanding, difficulty solving problem, problem stories

\section{(7) (2)}

This article is licensed under a Creative Commons AttributionShareAlike 4.0 International License.

\begin{abstract}
This research includes the kind of qualitative descriptive research aimed at knowing the factors of the cause of the difficulties of the students of class XII SMAN 27 Tangerang District in learning understanding as well as solving three dimensional geometry problems, particularly point-to-point distances, to lines, and to fields. The subject in this study was 35 academic year students 2019--2020 were selected in purposive sampling. Data collection is done with tests and interviews. The results of the research obtained, among others, a factor of understanding difficulty: 1) Students ' difficulties to imagine or visualize; 2) elaborate teacher explanation; 3) Lack of use of media/props in learning; 4) Students are less concerned with teachers during KBM; 5) low interest in learning; 6) Learning methods are ineffective. The students ' difficulty factor in solving three dimensional geometry problems, including: 1) do not understand the intent of the question; 2) wrong image; 3) Low basic understanding of concept calculations; 4) The experience of learning geometry at the previous school level is still lacking.
\end{abstract}

Abstrak: Penelitian ini termasuk jenis penelitian kualitatif deskriptif yang bertujuan untuk mengetahui faktor-faktor penyebab kesulitan siswa kelas XII SMAN 27 Kabupaten Tangerang dalam pemahaman belajar serta penyelesaian masalah geometri dimensi tiga khususnya jarak titik ke titik, ke garis, dan ke bidang. Subjek dalam penelitian ini adalah 35 orang siswa tahun akademik 2019--2020 yang dipilih secara purposive sampling. Pengumpulan data dilakukan dengan tes dan wawancara. Hasil penelitian yang diperoleh antara lain, faktor kesulitan pemahaman: 1) Kesulitan siswa untuk berimajinasi atau membayangkan; 2) Penjelasan guru yang rumit; 3) Kurangnya penggunaan media/alat peraga dalam pembelajaran; 4) Siswa kurang memperhatikan guru saat KBM; 5) Rendahnya minat belajar; 6) Metode pembelajaran tidak efektif. Adapun faktor kesulitan siswa dalam penyelesaian masalah geometri dimensi tiga, diantaranya: 1) Tidak memahami maksud soal; 2) Gambar yang salah; 3) Rendahnya dasar pemahaman konsep perhitungan; 4) Pengalaman belajar geometri pada jenjang sekolah sebelumnya masih kurang.

Correspondence Address: Jln. Raya Bogor KM.24 Cijantung Jakarta Timur, 13770 ,Indonesia; e-mail: arie_pk@stkipkusumnegara.ac.id

How to Cite (APA $6^{\text {th }}$ Style): Ayunigrum, L., Kusuma, A.P., Rahmawati, N. K. (2019). Analisis Kesulitan Siswa Dalam Pemahaman Belajar Serta Penyelesaiaan Masalah Ruang Dimensi Tiga. JKPM (Jurnal Kajian Pendidikan Matematika), 5 (1): 135-142.

Copyright: Ayunigrum, L., Kusuma, A.P., dan Rahmawati, N. K. (2019)

Competing Interests Disclosures: The authors declare that they have no significant competing financial, professional or personal interests that might have influenced the performance or presentation of the work described in this manuscript. 


\section{PENDAHULUAN}

Matematika merupakan ratu ilmu dalam pendidikan. Sebagaimana didukung pendapat Sundayana (dalam Aries: 2017) yaitu matematika merupakan salah satu komponen dari serangkaian mata pelajaran yang mempunyai peranan penting dalam pendidikan. Matematika dianggap memiliki peranan penting karena matematika memajukan daya pikir seseorang dengan cara membiasakan seseorang untuk berfikir sistematis,menganalisis keadaan dan kreatif menemukan hal-hal yang logis untuk menyelesaikan berbagai masalah dikehidupan. Matematika tidak hanya sekadar untuk perhitungan saja melainkan juga telah banyak digunakan untuk perkembangan berbagai ilmu pengetahuan lainnya. Karena jantung dalam matematika adalah pemecahan masalah sehingga konsep dalam matematika bisa dijadikan dasar pengembangan ilmu pengetahuan lain.

Salah satu cabang matematika yang erat kaitannya dengan kehidupan sehari-hari adalah geometri. Geometri memiliki peranan penting dalam pondasi dasar yang mendukung pnguasaan konsep aljabar,bilangan,aritmatika serta konsep matematika selanjutnya (Novita, R., Prahmana, R. C. I., Fajri, N., \& Putra, M.: 2018). Konsep geometri terhubung dengan konsep kehidupan sehari-hari dan sangat penting untuk peningkatan kemampuan berpikir tingkat tinggi. Menurut Rizal dalam (Bariansyah, R., Paloloang, B., \& Amri, B: 2016.) mengungkapkan bahwa geometri merupakan bagian dari matematika yang menempati posisi memprihatinkan dibandingkan cabang matematika yang lain. Oleh karena itu, geometri merupakan suatu hal yang perlu untuk dipelajari dan dikuasai dalam pembelajaran matematika.

Geometri dimensi tiga merupakan bagian dari geometri yang membahas tentang bangun ruang seperti kubus,limas dan sebagainya, serta membahas objek abstrak seperti titik, garis, dan bidang. Objek tersebut didapatkan melalui proses abstraksi benda-benda konkret dalam kehidupan sehari-hari (Novita, R., Prahmana, R. C. I., Fajri, N., \& Putra, M.: 2018). Karena objek yang abstrak, banyak siswa yang mengalami kesulitan baik dari segi pemahaman sampai pemecahan masalah. Materi ini memerlukan pemahaman khusus sehingga untuk mengoptimalkan hasil belajar siswa pada materi bangun ruang sisi datar diperlukan strategi dan model pembelajaran yang disesuaikan dengan minat siswa dalam rangka mencapai tujuan pembelajaran yang direncanakan (Kusuma, A. P., \& Susanty, I.: 2019) Dalam geometri dimensi tiga kunci untuk memecahkan suatu masalah yaitu pemahaman konsepnya. Namun pada kenyataannya, kebanyakan siswa yang konsep/dasarnya saja sudah mengalami kesulitan, dengan begitu siswa pun akan mengalami kesulitan dalam pemecahan masalah. Hal itu pun terjadi kepada siswa kelas XII IPA 4 di SMAN 27 Kabupaten Tangerang, dan kesulitan itu timbul akibat beberapa faktor, baik dari dalam maupun luar diri siswa. Keberhasilan proses pembelajaran secara umum khusunya pada pelajaran matematika terukur berdasarkan kemampuan siswa dalammengikuti kegiatan pembelajaran tersebut. Keberhasilan tersebut terlihat jika siswa memahami dan mempunyai nilai akhir yang baik. Semakin tinggi keberhasilan belajar menandakan pemahaman dan penguasaan materi serta hasil belajar juga meningkat (Rahmawati, N. K., \& Hanipah, I. R.: 2018)

Pada saat ini masih banyak guru menggunakan metode ceramah. Lemahnya proses pembelajaran menjadi salah satu bukti bahwa guru harus kreatif dan inovatif dalam proses belajar pembelajaran. Proses pembelajaran di dalam kelas diarahkan kepada kemampuan siswa untuk menghafal informasi, otak siswa dipaksa untuk mengingat dan menimbun berbagai informasi tanpa dituntut untuk memahami informasi yang diingatnya itu untuk menghubungkannya dengan kehidupan sehari-hari. Akibatnya, ketika siswa lulus dari sekolah, mereka pintar secara teoretis, tetapi mereka miskin aplikasi (Lutvaidah, U., \& Hidayat, R.: 2019). Aktivitas belajar tidak selamanya berlangsung secara wajar. Kadang-kadang lancar, kadangkadang tidak, kadang-kadang dapat cepat menangkap apa yang dipelajari, kadang-kadang terasa amat sulit. Dalam hal semangat terkadang semangatnya tinggi, tetapi terkadang juga sulit untuk mengadakan 
konsentrasi. Kenyataan yang sering kita jumpai pada setiap anak didik dalam kehidupan sehari-hari dalam kaitannya dengan aktivitas belajar. Setiap individu memang tidak ada yang sama. siswa cenderung lebih banyak diam, mendengar, dan menerima apa yang telah disampaikan oleh guru dan dalam proses pembelajaran belum menerapkan metode pembelajaran yang bervariasi sehingga siswa kurang aktif dalam mengikuti proses pembelajaran (Budiyanti, E., Kusuma, A. P., \& Arihati, D. B.: 2019) Perbedaan individual ini pulalah yang menyebabkan perbedaan tingkah laku belajar di kalangan anak didik. Dalam keadaan dimana anak didik/siswa tidak dapat belajar sebagaimana mestinya, itulah yang disebut dengan kesulitan belajar (Dalyono, 2012: 229). Definisi kesulitan belajar pertama kali dikemukakan oleh The United States Office of Education (USOE) pada tahun 1977 yang dikenal dengan Public Law (PL) 94 - 142, yang hampir identik dengan definisi yang dikemukakan oleh The National Advesory Committee on Handicapped Children pada tahun 1967 yang dikutip oleh Abdurrahman (2003: 06) menyatakan bahwa kesulitan belajar adalah gangguan dalam satu atau lebih dari proses psikologis dasar yang mencakup pemahaman dan penggunaan bahasa ujaran atau tulisan. Gangguan tersebut mungkin menampakkan diri dalam bentuk kesulitan mendengarkan, berpikir, berbicara, membaca, menulis, mengeja, atau berhitung. Definisi lain yang dikemukakan oleh The National Joint Commite for Learning Dissabilites (NJCLD) dalam Abdurrahman (2003: 07) menyatakan bahwa kesulitan belajar menunjuk kepada sekelompok kesulitan yang dimanifestasikan dalam bentuk kesulitan nyata dalam kemahiran dan penggunaan kemampuan mendengarkan, bercakap-cakap, membaca, menulis, menalar atau kemampuan dalam bidang studi matematika.

Sedangkan dalam PL 94-142, The Board of The Association for Children and Adult with Learning Dissabilities (ACALD) dalam Abdurrahman (2003: 08) mengemukakan definisi kesulitan belajar sebagai suatu kondisi kronis yang diduga bersumber neurologis yang secara selektif mengganggu perkembangan, integrasi, dan/atau kemampuan verbal dan/atau nonverbal. Kesulitan belajar tampil sebagai suatu kondisi ketidakmampuan yang nyata pada orangorang yang memiliki intelegensi rata-rata hingga superior, yang memiliki sistem sensoris yang cukup dan kesempatan untuk belajar yang cukup pula. Berbagai kondisi tersebut bervariasi dalam perwujudan dan derajatnya. Meskipun terdapat perbedaan pada tiga definisi yang telah dikemukakan, ketiganya memiliki titik kesamaan, yaitu adanya kesulitan dalam tugas-tugas akademik dan adanya kesenjangan antara prestasi dengan potensi. Ketiga definisi juga mengindikasikan bahwa kesulitan belajar dapat berwujud sebagai suatu kekurangan dalam satu atau lebih bidang akademik, baik dalam mata pelajaran yang spesifik seperti membaca, menulis, matematika, dan mengeja, atau dalam keterampilan yang bersifat lebih umum seperti mendengarkan, berbicara, dan berpikir. Ketiga definisi mengemukakan bahwa anak berkesulitan belajar memperoleh prestasi belajar jauh di bawah potensi yang dimiilikinya.

Di Indonesia belum ada definisi yang baku tentang kesulitan belajar. Para guru umumnya memandang semua siswa yang memperoleh prestasi belajar rendah disebut siswa berkesulitan belajar. (Abdurrahman, 2003: 09). Secara garis besar kesulitan belajar dapat diklasifikasikan dalam kesulitan belajar yang berhubungan dengan perkembangan dan kesulitan belajar akademik (Abdurrahman, 2003: 11). Kesulitan belajar akademik menunjuk pada adanya kegagalan-kegagalan pencapaian prestasi akademik yang sesuai dengan kapasitas yang diharapkan. Kegagalan-kegagalan tersebut mencakup penguasaan keterampilan dalam membaca, menulis, dan/atau matematika. Kesulitan belajar akademik dapat diketahui oleh guru atau orang tua ketika anak gagal menampilkan salah satu atau beberapa kemampuan akademik.

Berdasar pada permasalahan yang dialami siswa SMAN 27 Kabupaten Tangerang dalam pembelajaran geometri dimensi tiga serta kesulitan belajarnya, maka dianggap perlu dan penting untuk melakukan kajian analisis faktor penyebab kesulitan belajar dan pemecahan masalah dalam materi ruang dimensi tiga khususnya jarak titik ke titik, titik ke garis, dan titik ke bidang. 


\section{METODE}

Jenis penelitian yang digunakan adalah penelitian kualitatif deskriptif yang bersifat menganalisis kesulitan siswa dalam pemahaman belajar serta penyelesaian masalah ruang dimensi tiga. Subjek dalam penelitian ini adalah kelas XII IPA 4 SMAN 27 Kabupaten Tangerang. Triangulasi menurut susan Stainback dalam (Sugiyono: 2007) merupakan "the aim is not to determinate the truth about sam social phenomenon, rather tahn the purpose of triangulation is to increase one's understanding of what ever is being investigated". Dengan demikian triangulasi bukan bertujuan mencari kebenaran, tetapi meningkatkan pemahaman peneliti terhadap data dan fakta yang dimiliki. Pemeriksaan keabsahan dalam penelitian ini menggunakan teknik triangulasi. Teknik pengumpuan data dalam penelitian ini yaitu (a) tes yang diberikan untuk memperoleh data hasil pekerjaan siswa (b) wawancara yang dilakukan untuk mengetahui kesulitan siswa dalam pemahaman belajar serta pemecahan masalah di ruang dimensi tiga. (c) dokumentasi

\section{HASIL}

Penelitian diawali dengan mengamati proses belajar mengajar pada pokok bahasan ruang dimensi tiga. Pengamatan proses belajar mengajar dilaksanakan sebanyak 12 jam pelajaran atau 6 kali pertemuan. Tes diberikan pada siswa setelah selesai menerima materi ruang dimensi tiga (jarak titik ke titik, titik ke garis, dan titik ke bidang). Siswa diminta mengerjakan 4 soal untuk mengetahui letak kesulitan siiswa.

a. Jenis-jenis kesulitan siswa

Berdasar pada hasil dari teknik triangulasi ada 2 jenis kesulitan yang terjadi dalam materi ruang dimensi tiga khusunya jarak titik ke titik, titik ke garis, dan titik ke bidang. Yaitu kesulitan pemahaman materi (data yang diambil dari pengamatan, wawancara dan dokumentasi) dan kesulitan memecahkan masalah (data yang diambil dari tes, wawancara dan dokumentasi).

b. Kesulitan pemahaman belajar siswa

Kesulitan pemahaman belajar tentu memiliki faktor-faktor penyebab. Berikut contoh hasil wawancara siswa yang mengalami kesulitan pemahaman belajar. Data diambil saat siswa telah selesai pembelajaran/penerimaan materi. Hasil wawancara sebagai berikut:

P : "Apa yang membuat kamu bingung saat pelajaran materi jarak titik ke bidang?"

S1 : "Saya bingung sama gambarnya bu"

P : "Ada apa ? bukankah gambarnya sudah jelas dipapan?"

S1 : "Ya bu, tapi saya tidak bisa membayangkan letak jarak dari titik A ke titik TBC"

P : "Bukankah sudah ibu kasih spidol warna untuk membedakan garis dan bangunnya?"

S1 : "Tetap tidak terbayang bu, tidak nyata jadi sulit terbayang"

Berdasar pada hasil wawancara diketahui bahwa siswa mengalami kebingungan dalam pembelajaran ruang dimensi tiga dikarenakan kesulitan membayangkan ruang dimensi tiga walaupun sudah tergambar dua dimensi dengan jelas sehingga siswa membutuhkan alat peraga/media pembelajaran untuk membantu membayangkan materi tersebut. Pendapat ini juga didukung oleh penelitian Novita, R., Prahmana, R. C. I., Fajri, N., \& Putra, M. (2018) yang menyatakan penyebab kesulitan siswa salah satunya adalah kurangnya penggunaan media konkret seperti alat peraga oleh guru sehinggga hal yang bersifat abstrak susah di bayangkan (kesulitan melukis bangun ruang, kesulitan membayangkan benda/unsur yang tidak nampak, dan siswa dituntut untuk menghayal).

Adapun faktor lain yang menyebabkan siswa kesulitan berdasarkan hasil wawancara dengan siswa yang berbeda sesaat setelah pemberian contoh jarak titik ke garis. Hasil wawancaranya sebagai berikut:

P : "Apa ada yang tidak dimengerti dari contoh soal tersebut?" 
S2 : "Ada Bu, kok itu tiba-tiba seperti itu bagian itu Bu ? Tadi saya terlewat karena teman mengajak untuk mengobrol sesuatu sebentar"

P : "Itu menggunakan Teorema Phytagoras karena segitiganya siku-siku"

S2 : "Jika segitiganya sama sisi bagaimana Bu?"

$\mathrm{P} \quad$ : "Jika segitiga sama sisi maka ketika ditarik garis akan membagi sama besar, sehingga segitiga sama sisi terdiri dari dua segitiga siku-siku dan dapat digunakan Teorema Phytagoras"

S2 : "Jika segitiga sama kaki dan segitiga sembarangan bagaimana Bu?"

$\mathrm{P}$ : "Segitiga sama kaki bisa digunakan Teorema Phytagoras jika memenuhi beberapa kondisi tertentu. Namun juga bisa pakai rumus luas segitiga untuk menentukan jaraknya. Kalau segitiga sembarang menggunakan luas segitiga untuk mencari jaraknya"

S2 : "Oh begitu ya Bu membedakannya. Terima kasih, Bu. Memang saya yang kurang memperhatikan dan malas, makanya kurang mengerti materi ini. Karena susah Bu materi ini”

Berdasar pada hasil wawancara diatas diketahui siswa kurang memperhatikan guru saat menjelaskan dan itu disebabkan karena siswa tersebut menganggap materi ruang dimensi tiga sulit unutk dipelajari sehingga minat belajarnya rendah. Pada wawancara, ketika siswa bertanya beberapa perbedaan teori segitiga itu menandakan bahwa siswa tersebut kesulitan dalam memahami konsep mengukur jarak dengan beberapa teorema.

Dapat disimpulkan dari beberapa contoh hasil pengamatan serta wawancara bahwa faktor-faktor yang menyebabkan siswa kesulitan dalam memahami pembelajaran materi ruang dimensi tiga adalah: 1) siswa kurang memahami konsep segitiga 2) rendahnya minat belajar siswa sehingga siswa menjadi kurang memperhatikan dan malas.

c. Kesulitan siswa dalam penyelesaian masalah

Permasalahn dalam materi ruang dimensi tiga umunya berupa soal cerita. Soal cerita memuat pertanyaan yang menuntut pemikiran dan langkah-langkah penyelesaian secara sistematis. Jadi siswa dituntut untuk menganalisis unsur yang diketahui, kemudian menggambar bangunnya, setelah itu mengerjakan sesuai konsep yang sudah dipelajari. Namun pada kenyataannya banyak yang kesulitan siswa dalam pemecahan masalahnya. Berikut contoh hasil kerja serta wawancara siswa yang mengalami kesulitan pemecahan masalah ruang dimensi tiga.

Soal: Dari limas segitiga T.ABC, diketahui bahwa segitiga $A B C$ siku-siku di titik $B$. $A B=12 \mathrm{~cm}, B C=$ $16 \mathrm{~cm}, \mathrm{~TB}=24 \mathrm{~cm}$, dan garis $\mathrm{TB}$ tegak lurus bidang $\mathrm{ABC}$. Hitunglah jarak antara titik $\mathrm{T}$ dan titik tengah $\mathrm{AC}$ !

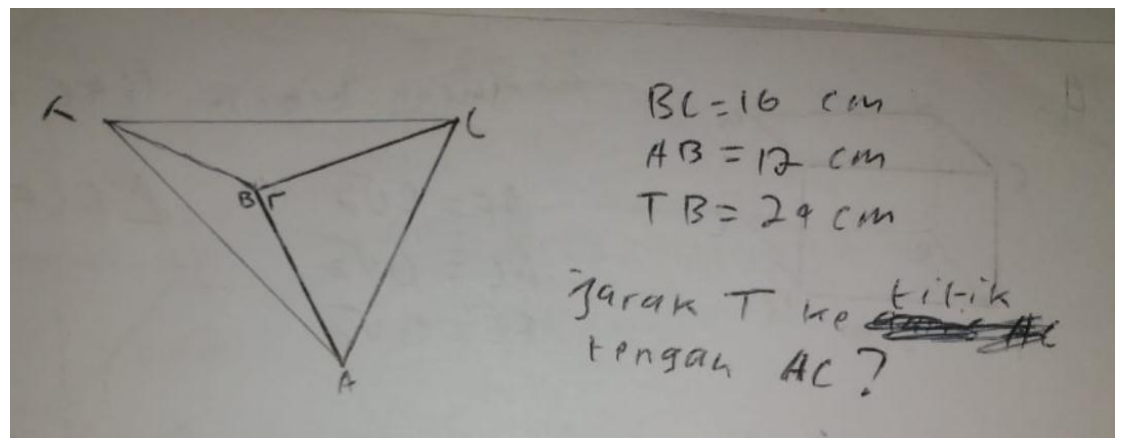

\section{Gambar 1. Hasil kerja siswa soal no. 1}

Berdasar pada hasil kerja siswa, siswa tersebut sudah bisa menganalisis unsur yang diketahui, namun dalam penggambaran bangunnya kurang tepat sehingga kesulitan untuk menyelesaikannya. Pendapat itu didukung dengan wawancara pada siswa terebut: 
P : : "Itu soal nomor 1 tidak diselesaikan ?"

S3 : "Bingung Bu maksut dari keterangan soalnya, bingung juga gambarnya seperti apa"

$\mathrm{P} \quad$ : "Memangnya harus digambar? Kan tidak ada perintah untuk menggambar?"

S3 : "Ya biar tau Bu jaraknya yang mana. Biar kebayang Bu"

$\mathrm{P} \quad$ : "Menurutmu sudah benar itu gambarnya?"

S3 : "Belum $\mathrm{Bu}$, saya bingung"

Berdasar pada hasil wawancara tersebut diketahui bahwa siswa tidak dapat menyelesaikan permasalahan akibat tidak mampu mencerna dengan baik soal tersebut, serta tidak mampu menggambarkan bangun tersebut dengan benar.

Selain itu adalagi faktor kesulitan siswa dalam pemecahan masalah . berikut hasil kerja siswa beserta wawancara pada siswa berbeda pada soal nomor 3

Soal: diketahui limas segiempat beraturan $T$. $A B C D$ dengan $A B=B C=5 \sqrt{2} \mathrm{~cm}$. Dan $T A=13 \mathrm{~cm}$. Tentukan jarak titik A ke garis TC!

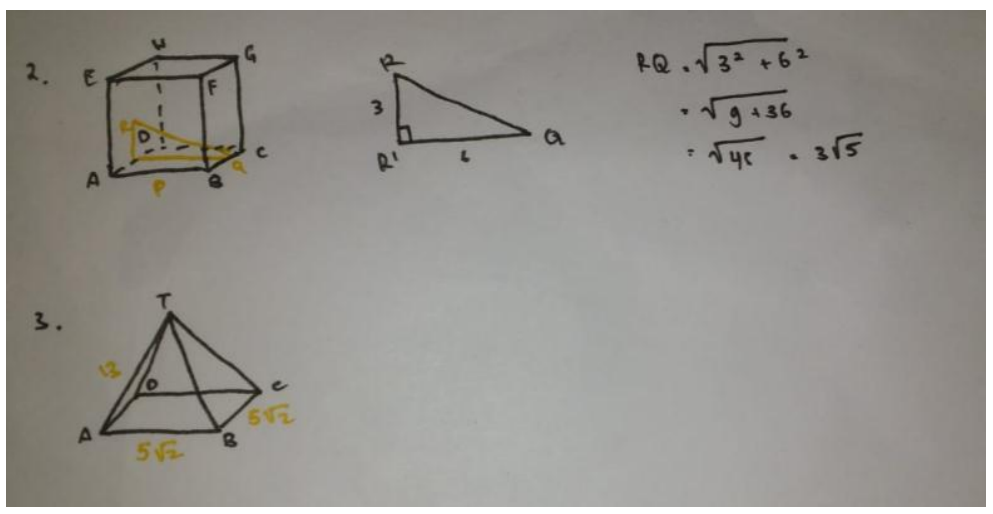

Gambar 2. Hasil kerja siswa soal no.3

Berdasar pada hasil kerja siswa tersebut sudah benar dalam menggambar sesuai keterangan dan sudah benar dalam penempatan angkanya, tetapi belum diselesaikan. Berikut keterangan siswa tersebut dalam wawancara:

P : "Itu nomor 3 kok tidak diselesaikan?"

S4 : "Saya lupa Bu caranya"

$\mathrm{P} \quad$ : "Itu yang nomor 2 sudah selesaikan. Kan sama konsepnya"

S4 : "Itu kan kubus Bu, ini mah limas"

P : "Memangnya kenapa? Kan konsepnya mirip bahkan sama"

S4 : "Beda Bu, kubus mah udah terbayang karena ukurannya yang jelas dan sama, sudah sering juga saat SMP belajar kubus. Jadi paham kalau tentang kubus, kalau limas tidak terbayang $\mathrm{Bu}$, sulit dipahami"

P : "Berapa kali kamu latihan soal tentang Limas dan Prisma"

S4 : "Cuma waktu ada PR Bu, selain itu tidak pernah"

Berdasar pada hasil wawancara diatas dapat dianalisis bahwa anak tersebut tidak menyelesaikan permasalahan yang ada karena lupa tentang konsep limas serta kurangnya latihan pada bangun ruang limas. Dengan kata lain siswa tersebut hanya mengahafal konsep tanpa memahami dalam arti belajar bermakna.

Dapat disimpulkan dari beberapa hasil kerja siswa dan wawancara, faktor-faktor yang menyebabkan siswa kesulitan pemahaman masalah ruang dimensi tiga yaitu: 1) tidak memahami maksud soal, 2) siswa hanya menghafal konsep sehingga diberikan soal yang lain kebingungan. 


\section{PEMBAHASAN}

Geometri merupakan cabang matematika yang erat kaitannya dengan kehidupan sehari-hari. Geometri dimensi tiga memepelajari tentang bangun ruang serta unsurnya yaitu titik, garis, dan bidang. Meskipun erat kaitannya dengan konteks kehidupan, namun geometri merupakan cabang matematika yang pemahamannya ada di tingkat memprihatinkan sehingga perlu dianalisis penyebab kesulitan-kesulitan siswa yang dihadapi. Terdapat dua jenis kesulitan siswa dalam mempelajari geometri dimensi tiga atau ruang dimensi tiga yaitu kesulitan dalam pemahaman belajar dan kesulitan dalam menyelesaikan permasalahan yang ada. Setiap kesulitan tentunya memiliki faktor-faktor penyebabnya.

Berdasar pada hasil wawancara diketahui bahwa siswa mengalami kebingungan dalam pembelajaran ruang dimensi tiga dikarenakan kesulitan membayangkan ruang dimensi tiga walaupun sudah tergambar dua dimensi dengan jelas, sehingga siswa membutuhkan alat peraga/media pembelajaran untuk membantu membayangkan materi tersebut. Pendapat ini juga didukung oleh penelitian Rita, Rully, Nurul, dan Mulia (2018) selain itu faktor-faktor yang menyebabkan siswa kesulitan dalam memahami pembelajaran materi ruang dimensi tiga adalah 1) siswa kurang memahami konsep segitiga; 2) rendahnya minat belajar siswa sehingga siswa menjadi kurang memperhatikan dan malas. Sebagaimana yang dijelaskan oleh Dalyono (2009: 235) bahwa belajar yang tidak ada minatnya mungkin tidak akan sesuai dengan kebutuhan, tidak sesuai dengan kecakapan, tidak sesuai dengan tipe-tipe khusus anak dan banyak menimbulkan problema pada dirinya. Dan faktor-faktor yang menyebabkan siswa kesulitan pemahaman masalah ruang dimensi tiga yaitu: 1) tidak memahami maksud soal; 2) siswa hanya menghafal konsep sehingga diberikan soal yang lain kebingungan. Kesalahan-kesalahan yang telah diuraikan mungkin dikarenakan siswa tidak memahami bahasa soal sehingga tidak mampu menyusun algoritma yang sesuai. Kemungkinan lain adalah siswa tidakmemahami prinsip-prinsip apa yang terlibat dalam masalah yang dimunculkan soal, juga tidak memahami konsep yang terkait. Mungkin juga siswa tidak dapat memisahkan faktor-faktor yang relevan yang terlibat di dalamnya. Prinsip hanya dihafalkan, tanpa tahu makna dan relasi antar konsepnya. Untuk itu siswa harus memahami masing-masing pernyataan yang terdapat pada soal, memahami makna pertanyaan yang diajukan, membuat strategi atau perencanaan untuk memecahkan permasalahan yang diberikan, menggunakan algoritma dan menghitung yang tepat. (Syahrir, S., Kusnadin, K., \& Nurhayati, N: 2013).

\section{SIMPULAN}

Berdasar pada hasil penelitian, dapat disimpulkan bahwa kesulitan belajar siswa adalah kurang memahaminya konsep tentang ruang dimensi tiga. Sementara itu, untuk mengatasi kesulitan belajar tersebut, alternatifnya adalah guru selama proses pembelajaran berlangsung, hendaknya menggunakan media pembelajaran berupa alat peraga berupa benda-benda konkret di sekitar lingkungan sekolah maupun lingkungan rumah, sehingga memudahkan pemahaman konsep ruang dimensi tiga dan dapat membantu siswa meningkatkan pemahaman, memudahkan penafsiran, serta membangkitkan motivasi dan minat siswa. 


\section{DAFTAR RUJUKAN}

Abdurrahman, M. (2003). Pendidikan Bagi Anak Berkesulitan Belajar. Jakarta: Rineka Cipta.

Bariansyah, R., Paloloang, B., \& Amri, B. (2016). Profil Kemampuan Siswa Menentukan Jarak Dua Bidang Dirung Dimensi Tiga Berdasarkan Tingkat Kemampuan Menyelesaikan Try Out Ujian Nasional Matematika di SMA Al-Azhar Palu. Aksioma Jurnal Pendidikan Matematika, 5 (1), 39-53

Budiyanti, E., Kusuma, A. P., \& Arihati, D. B. (2019). Penerapan Metode MMP dan NHT terhadap Hasil Belajar Matematika pada Materi Trigonometri. Buana Matematika: Jurnal Ilmiah Matematika dan Pendidikan Matematika, 9 (1), 25-30.

Dalyono, M. (2012). Psikologi Pendidikan. Jakarta: Rineka Cipta.

Kusuma, A. P., \& Susanty, I. (2019). Eksperimentasi Model Pembelajaran Nht Dan Snowball Throwing Pada Materi Bangun Ruang Sisi Datar Kelas VIII SMP Al-Nur Cibinong. Jurnal Pendidikan Matematika dan IPA, 10 (1), 52-62.

Kusuma, A. P., \& Budiyono, B. (2015). Eksperimentasi Model Pembelajaran TTW dan TPS Pada Materi Bangun Ruang Sisi Datar Ditinjau Dari kemampuan Penalaran Matematis Siswa. Jurnal Pembelajaran Matematika, 3 (2).

Lutvaidah, U., \& Hidayat, R. (2019). Pengaruh Ketelitian Membaca Soal Cerita terhadap Kemampuan Pemecahan Masalah Matematika. JKPM (Jurnal Kajian Pendidikan Matematika), 4 (2), 179-188.

Novita, R., Prahmana, R. C. I., Fajri, N., \& Putra, M. (2018). Penyebab kesulitan belajar geometri dimensi tiga. Jurnal Riset Pendidikan Matematika, 5 (1), 18-29.

Rahmawati, N. K., \& Hanipah, I. R. (2018). Penerapan Model Pembelajaran Kooperatif Tipe Think Pair Share (TPS) Dan Model Pembelajaran Kooperatif Tipe Student Team Achievement Division (STAD) Terhadap Hasil Belajar Matematika Siswa Pada Materi Garis Singgung Lingkaran. NUMERICAL: Jurnal Matematika dan Pendidikan Matematika, 2 (1), 99-114

Sugiyono. (2007). Metodologi Penelitian Pendidikan. Bandung: Alfabeta.

Syahrir, S., Kusnadin, K., \& Nurhayati, N. (2013). Analisis kesulitan pemahaman konsep dan prinsip materi pokok dimensi tiga siswa kelas XI SMK Keperawatan Yahya Bima. Prisma Sains: Jurnal Pengkajian Ilmu dan Pembelajaran Matematika dan IPA IKIP Mataram, 1 (1), 89-103. 